\title{
A!
}

This is an electronic reprint of the original article.

This reprint may differ from the original in pagination and typographic detail.

Lavikka, Rita; Kyrö, Riikka; Peltokorpi, Antti; Särkilahti, Anna

\section{Revealing Change Dynamics in Hospital Construction Projects}

\section{Published in:}

Engineering, Construction and Architectural Management

DOI:

10.1108/ECAM-03-2018-0119

Published: 21/10/2019

Document Version

Peer reviewed version

Please cite the original version:

Lavikka, R., Kyrö, R., Peltokorpi, A., \& Särkilahti, A. (2019). Revealing Change Dynamics in Hospital

Construction Projects. Engineering, Construction and Architectural Management, 26(9), 1946-1961.

https://doi.org/10.1108/ECAM-03-2018-0119

This material is protected by copyright and other intellectual property rights, and duplication or sale of all or part of any of the repository collections is not permitted, except that material may be duplicated by you for your research use or educational purposes in electronic or print form. You must obtain permission for any other use. Electronic or print copies may not be offered, whether for sale or otherwise to anyone who is not an authorised user. 
Lavikka, R., Kyrö, R., Peltokorpi, A. \& Särkilahti, A. (2019) Revealing Change Dynamics in Hospital Construction Projects, Engineering, Construction and Architectural Management (published in May 2019, early cite), https://www.emeraldinsight.com/doi/abs/10.1108/ECAM-03-2018-0119.

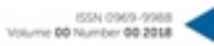

Engineering, Construction

and Architectural

Management

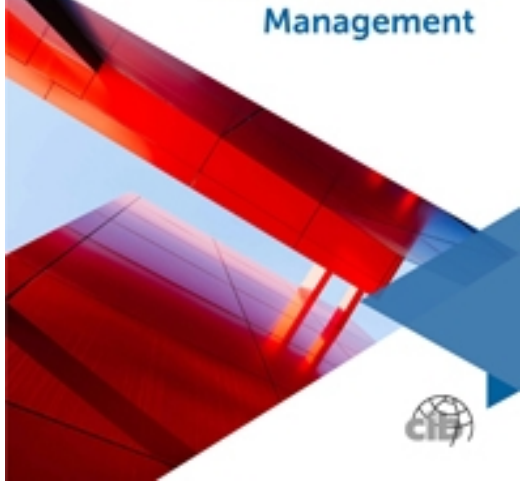

\section{Revealing Change Dynamics in Hospital Construction Projects}

\begin{tabular}{|r|l|}
\hline Journal: & Engineering, Construction and Architectural Management \\
\hline Manuscript ID & ECAM-03-2018-0119.R1 \\
\hline Manuscript Type: & Original Article \\
\hline Keywords: & Project Management, Construction, Case Study \\
\hline Abstract: & \\
\hline
\end{tabular}

\section{SCHOLARONE ${ }^{\text {M }}$}

Manuscripts 


\title{
Revealing Change Dynamics in Hospital Construction Projects
}

\begin{abstract}
Purpose - Hospital construction projects often suffer from relatively late changes in the project lifecycle, which disrupt the project execution and impact project productivity. This paper explores the root causes of changes in hospital construction projects. The paper aims to propose ways to prepare for the changes.

Design/methodology/approach - The study focuses on changes during the construction of new hospital facilities. An explorative, case study research design is utilised. Five case projects from Finland, Sweden, and the USA were selected for in-depth analysis. The primary data comprises semi-structured interviews, supported by secondary evidence such as change order documents.

Findings - The findings reveal eight categories for change sources: Contracts, and Equipment and systems are reflective of the fast-paced healthcare technology and changing user requirements, while External environment comprises changes caused by both regulatory and physical environment. Changes in Operations are reflected in the continuous development of treatment methods and processes. The User, Owner, Designer, and Contractor initiated changes represent the stakeholder influence. The paper makes a connection between these change sources and project complexity dimension. A framework for change dynamics is introduced, and product and process flexibility is suggested as a suitable method to prepare for and manage changes.

Originality/value - The paper is the first to link construction changes to project complexity factors. The paper argues that changes, when managed appropriately, are not only necessary but also beneficial to large construction projects in a quickly changing environment. The findings guide project stakeholders in implementing project flexibility, in the product and process dimensions, which is a balancing force to project complexity.
\end{abstract}

Keywords Project management, Construction, Case Study

Paper type Research paper 


\section{Introduction}

The advancements in healthcare technology and operations are likely to accelerate in the future. Trends like mobile and telehealth, self-treatment, and day surgery are changing healthcare facility needs. Hospital buildings face many uncertainties during their life-cycle, for example changing user requirements or operations (Barlow and Köberle-Gaiser, 2009). The design and construction phases of technically complex hospitals usually take more than ten years, during which changes in the operational environment take place (Sebastian, 2011). For example, during the construction phase, the owner may want to change the spatial program due to changes in the models of care delivery or hospital business models, or the owners may find out that they have less financial resources than initially planned to build the hospital (Lavikka et al., 2015). Notwithstanding, changes in construction projects have been recognised as a primary cause for cost and schedule overruns as well as a source of dispute between project parties (Love and Edwards, 2004; Olawale and Sun, 2010). For example, financial challenges and the lack of coordination have been found as the main factors causing delays in construction projects (Alaghbari et al., 2007). Moreover, hospital projects seem to be facing more changes than other types of construction, often during the late project phases (Sebastian, 2011). The need for more flexibility, innovation and higher environmental standards in hospital construction projects is prevalent (Pauget and Wald, 2013).

According to the traditional view of project management, flexibility and change are seen as something to avoid, whereas careful planning and clear definitions are seen as critical success factors for projects (Olsson and Hansen, 2010). The dynamism and uncertainty stemming from the hospital construction project's context challenge the traditional pursuit of stability in project management (Olsson, 2006). However, not all changes in projects stem from actual changes in the project context but rather emerge with a better understanding of the stakeholders' needs and their ability to tell about them (Olsson, 2006). Typically, literature does not address the issue of changing customer requirements but focuses predominantly on finding the guilty party. This view is both simplistic and unconstructive. Project success should not be seen merely as conformance to plans but primarily as delivering customer value (Hellström and Wikström, 2005). Furthermore, projects should not be considered as closed but dynamic and open systems where management should enable the joint value creation 
of the participating actors over the system's lifecycle while taking into account the customer expectations (Lehtinen et al., 2019).

Dynamism and uncertainty originate from the high level of technical complexity of hospitals, decisionmaking complexities due to several stakeholders with hierarchical relationships, and the fast developments in the medical world (Sebastian, 2011). Classical project management techniques are in many ways not suitable to deal with this kind of goal uncertainty (Williams, 1999), and "one-size-fits-all" type of approaches are not able to match the varieties of contexts where projects are carried out (Shenhar and Dvir, 1996; Maylor et al., 2008). The reason may be that previous literature on construction project management has not focused on understanding how the different complexity factors arising from the hospital construction environment affect project execution. Therefore, more understanding is needed on the root causes of changes in hospital construction projects and how to prepare for the changes. This paper aims to contribute to this research gap by answering the question of what the root causes of changes in hospital construction projects are and how to prepare for them.

This paper sets to explore the root causes of changes during the construction phase of hospital construction projects to propose better ways to manage changes in hospital construction projects. A change is defined as an event that affects the project scope, designs, contract requirements, or other assumptions, which have previously been considered as final. The focus of analysis is on the relationship and agreements between the different stakeholders, and how changes appear and are handled in that context. In practice, this is demonstrated through the change order process. Further, this research is focused on changes during the construction phase, when a contractor has been chosen, and the detailed design is finished. All changes taking place after the release of the drawings for construction are considered construction phase changes in concurrent design and construction projects.

An explorative, case study research design is utilised to study changes during the construction of new hospital facilities. Five case projects from Finland, Sweden, and the USA were selected for in-depth analysis. The primary data comprises semi-structured interviews, supported by secondary evidence such as change order 
documents. The analysis of the data was guided by a literature review on the topics of complexity and flexibility in hospital construction projects and change management in construction projects.

The article is structured as follows. Next, the literature review introduces complexity and flexibility as essential themes in hospital construction projects as well as change management in construction projects. The following section is focused on explaining the research design. In the consequent section, key research findings are presented and discussed in the light of previous research. Finally, a summary of the conclusions is formed, the limitations of the study are visited, and new research avenues proposed.

\section{Literature review}

First, the literature review discusses project complexity to provide background for hospital construction and frame the research problem. Then, the literature on change causes, especially in hospital construction projects is discussed because contextual factors have been recognised to have a significant impact on project planning and change management subjects (Dvir and Lechler, 2004). Project flexibility is introduced as a mechanism to prepare for changes.

\subsection{Complexity in hospital construction projects}

Hospital construction projects differ from other types of construction in several ways. Hospitals typically have a lifespan of 40 years or even more, which creates high uncertainty. The planning and design phase can take about 10 to 20 years, during which many internal and external environmental changes take place. (Olsson and Hansen, 2010; Pauget and Wald, 2013) For example, the demand for medical treatment by areas or economic situation for financing the project may change. Changes in regulations, demographics, or medical technology also create uncertainty. Thus, hospital projects are considered uncertain, as they involve technical, organisational, and social aspects that are beyond the control of the project team. (Olsson and Hansen, 2010; Pauget and Wald, 2013)

Hospital construction projects are typically labelled as complex projects, but the linkage to complexity literature has not thoroughly been made to evaluate how the different complexity factors arising from the 
unique project environment affect hospital construction. Complex projects are usually large or technologically advanced projects, but complexity comes both from the technical definition of the project and from the management task which is a subjective perception of the project manager (Maylor et al., 2008). Bakhshi et al. (2016) add that complexity also originates from the interdependence of elements, non-linear and networked causality, and dynamic and emergent behaviour. However, no generally accepted definition for project complexity exist.

Researchers have operationalised the concept of project complexity by creating typologies with specific dimensions. For example, Williams (1999) proposes two dimensions of project complexity: structural complexity stemming from the number of elements and their interdependency, and uncertainty either in project goals or in the methods of achieving those goals.

In later studies, further dimensions to the concept of project complexity have been included. Geraldi et al. (2011) add dynamics, pace and socio-political dimensions to the two previously mentioned categories of structural and uncertainty. Dynamics refers to changes happening in the dimensions of complexity, such as "dynamic structural complexity" from changes in scope or "dynamic uncertainty" from the emergence of new technology during the project. Thus, dynamics is also linked to the uncertainty dimension. Pace is the temporal aspect of complexity. Tight timeframes intensify other types of complexities, for example by requiring new types of processes such as concurrent design, which increases ties between project components; thus increasing the structural complexity. Socio-political complexity arises from stakeholders; the people who influence and carry out the project, their interaction, joint sense-making process, and the establishment of common goals. Socio-political complexity adds emphasis on the human dimension in project management. Figure 1 illustrates the different dimensions of project complexity and examples of complexity indicators.

\footnotetext{
*** INSERT FIGURE 1 HERE ***

** Figure 1 caption: The dimensions of project complexity and examples of complexity indicators. **
} 
Theory on project complexity provides a viewpoint to understand specific difficulties stemming from changes during hospital construction projects. Theory reveals that the dimensions of project complexity affect each other. For example, if there is uncertainty in the requirements, and the requirements are not frozen, or they have to be changed later on, unexpected results that lead to cross-impacts between tasks, feedback loops, and rework may take place. Changes and rework might add more structural complexity, which increases the complexity of the project. (Williams, 1999) This study utilises the project complexity division by Geraldi et al. (2011) to interpret the empirical evidence as their division provides a structured way to operationalise the concept of complexity.

It is important to recognise that complexity can also be self-induced from several decisions made when planning and executing the project. The 'continuous' information flow between the users of the hospital and the project is of vital importance. Barlow and Köberle-Gaiser (2008) noticed that some hospital owners approach the project with an idea of a "ready-made house" without understanding the importance of continuously providing information for the project. The authors stated that the more complex the communication interface between the project and the hospital operational system was, the less adaptable the result was. Also, low budget allocation from the owners tend to work against flexibility in the product (Barlow and Köberle-Gaiser, 2008) and encourages short-term thinking.

\subsection{Change management in construction projects}

Change management is a crucial part of construction project management (Senaratne and Sexton, 2009). Change management in construction projects rests on a change management process that includes five action steps: promote a balanced change culture, recognise change, evaluate change, implement change, and improve based on the analysis of the change (Sun et al., 2006). Thus, the goal of finding the causes of change is usually to predict, proactively manage and prevent changes from happening (Sun and Meng, 2009; Zhao et al., 2010).

One hindrance in developing an overarching 'causes of change' taxonomy is the specific contextual factors present in different types of projects, which call for more specific tools to produce practically useful findings. 
The need to empirically study influencing factors and causes of change, especially from a social perspective, has been recognised (Dvir and Lechler, 2004; Sun et al., 2006). In order to understand the root causes of change, it is essential to consider the people, their motives and the decision-making processes influencing the changes. It has also been noted that in reality a single change can originate from a variety of factors, direct or indirect, and thus any simplified categorisation will lack this complexity (Sun and Meng, 2009).

Many studies have been conducted on change management in construction projects, primarily focusing on the causes of change, but few studies have focused on change management in the context of hospital construction projects that face more changes than other types of projects. Sivunen et al. (2014) studied the design phase of a healthcare centre in Finland, and they found that the current construction management practices are based on the assumption that the functions of the facility user remain unchanged, whereas, in reality, it is the opposite. The authors propose a design alliance as a method to solve this challenge. Shipton et al. (2014) conducted an ethnographic study to understand the process of making changes to requirements in a public sector hospital project in the UK. The researchers found that the change management procedures acted as boundary objects between the project stakeholders allowing them to collaboratively agree on changes and coordinate the work of managing changes (Shipton et al., 2014).

Studies on change management in other large construction projects are numerous. Ibbs (1997), for example, studied big construction projects in process-based industries, such as refinery, manufacturing, petroleum, and pharmaceutical, and divided the causes of changes to design errors and omissions, design changes, and external causes. Cox et al. (1999), on the other hand, studied three reasonably large (£2.6 - 22 million) construction projects (a university library and shopping centre, Heathrow cargo building, and Marks\&Spencer Preston refurbishment), and identified five typical causes of change: designer omissions in tender documents, coordination defects, shop drawing coordination, changes in client requirements, as well as new information on site conditions. No further commonalities in causes of change could be found between the cases, and no attempt was made to conduct a root cause analysis or categorise the changes (Cox et al. 1999), which highlights the difficulty of comparing and drawing conclusions between different project contexts in case studies. For this reason, research in the context of hospital projects is required to understand how the specific characteristics of hospital projects impact on change management. 
The most influential change causes regarding frequency and effects also tend to vary by context. For example, Hsieh, $\mathrm{Lu}$, and $\mathrm{Wu}(2004)$ investigated building and civil construction projects in Taiwan and attributed the most influential changes to problems in design and planning activities, such as mistakes and omissions. Burati Jr., Farrington, and Ledbetter (1992), on the other hand, studied nine industrial construction projects and discovered that most significant design changes were due to technical advancements, operational process changes in the use of the building, and client-initiated changes. All the studies above seem to consider causes and effects of changes as discrete from the contextual factors of the project, whereas this study aims to consider all contextual factors arising from the internal and external project environment.

As a summary, Sun and Meng (2009) introduce a taxonomy of three types of change causes in construction projects: external, project internal, and organisational. The first type of causes, external causes affect the project from outside and consist of PESTE factors: Political (government policies and planning permissions), Environmental (conservation restrictions, weather and geological conditions), Social (demographic changes, skill shortages and neighboring communities), Technological (new materials, construction methods and technological complexity), and Economic factors (economic cycle, inflation and market situation). The second type of causes, project internal causes, originate from project-specific sources, such as Client generated (requirement change, funding, decision making), Design consultant generated (incomplete documentation, errors, and omissions), Contractor/subcontractor generated (poor plan/schedule, delays, productivity issues), and Other causes, such as poor communication, team instability, and inappropriate organizational structure. The third type of causes, organisational causes, include Process related (business strategy and procedures), People related (competence, skills, culture, and ethics), as well as Technology related, such as IT and communication systems and technical support causes.

Project flexibility can be considered as a mechanism to prepare for project complexity. Project complexity can be divided into product and process flexibility, which can be used in combination or separately. Product flexibility is the ability of the product to adjust to changes even after the design is frozen, for example, by incorporating options for easier modification in the future. Product flexibility allows decision making under uncertainty. Process flexibility can be executed by delaying construction tasks until a final design decision is made. Process flexibility necessitates that the design-decision process and the construction process are 
synchronised to reach the desired effects. (Gil et al., 2005) Flexibility can also be applied in contracts and relationships between team members (Zhang et al., 2013). 


\section{Research design}

An exploratory, multiple case study design was chosen in an attempt to thoroughly understand the root causes of changes and propose ways to manage changes in hospital construction projects. The exploratory research attempts to increase understanding and seek new insights into a particular problem (Saunders, Lewis, \& Thornhill, 2007). A case study approach was chosen because the phenomenon of change during the construction phase needs to be investigated in its context of hospital construction projects. According to Yin (2003), case studies are best suited for investigating contemporary phenomena in their real-life contexts.

The research process started with broad research questions, and an inductive approach was used during the data collection. Data collection was not conducted with any hypothesis in mind to allow themes to arise from the interviews. However, research literature was used to find relevant theoretical perspectives through which the findings could be presented and linked to research on change management in construction. This approach is a viable means to direct the analysis, as Saunders et al. (2007) have suggested.

\subsection{Case selection}

A purposive sampling strategy was utilised for case selection. An international construction company offered to provide access to some hospital construction projects they had been involved with and were able to provide the contact details of some key personnel from the project teams. In the case selection, variation regarding hospital type, project budget, and the location were ensured to create a heterogeneous sample. The heterogeneous or maximum variation sampling is helpful in identifying patterns which are of particular interest and value (Saunders et al., 2007). Subsequently, five hospital construction projects were chosen: two from Finland, two from Sweden, and one from the US. The total project budgets ranged from 30 million to 200 million and included hospitals for various types of psychiatric and somatic care. Table 1 presents the case projects. 


\subsection{Data collection and analysis}

The primary data comprises semi-structured interviews with open-ended questions, allowing for flexibility with the order and logic of questioning (Saunders et al., 2007). Altogether, twenty-four interviews with key project personnel were conducted, sixteen of which in person and the remaining eight as telephone interviews. The interviews took place between October and December 2016. The aim was to interview people representing different key stakeholders in the project, and interviewees were asked to name additional people for interviews, i.e., snowball sampling was used (Biernacki and Waldorf, 1981). On a few occasions, a person of interest could not be reached, but all those who were reached were willing to be interviewed. The interview lengths ranged between half an hour and two hours.

An interview protocol was created to ensure a comparative data collection method. The protocol was followed in a flexible manner and modified based on the interviewee and their responses to previous questions. The interviewees were asked to provide background information on themselves and their projects, clarification on the change order process and the people involved, and changes and their management in the hospital projects. Most interviews were attended by two or three researchers to reduce researcher bias. The researchers took notes during the interviews, but the interviews were also recorded and subsequently transcribed verbatim for analysis purposes.

Secondary data was also gathered to ensure sufficient data triangulation, which is an integral part of the case study design according to Yin (2003). This data comprises of project presentations, change order data, meeting 
minutes from site meetings, and site observation during research visits. Additionally, publicly available information about the projects from online sources was utilised as supporting data. Table 2 lists the informants' organisation, role, the project they are representing, and the date of interview.

The reliability of this study is maintained by providing a detailed description of the data collection and the analysis processes. The presence of multiple researchers in the interviews and data analysis reduces the possibility of researcher bias and provides triangulation. Interviewee bias is reduced by including persons from different roles, organisations, and countries, as well as by providing anonymity to the respondents by concealing their names, organisations, and the exact projects researched. Internal validity is supported using data triangulation from multiple different sources of evidence and ensuring that all data, not only the converging part, is represented in the analysis.

\section{*** INSERT TABLE 2 HERE ***}

** Table 2 caption: Informants' organisation, role, and project.**

Interview transcripts were analysed with a qualitative data analysis software. Coding was done based on preliminary code categories stemming from the literature, such as change causes and change effects. More code categories were added as the coding progressed, such as different contextual variables, communication, design, and mitigation tools. Another method for processing the interview data was to list the examples gathered by using the "critical incident technique" described by Saunders et al. (2007), where respondents were told to give examples of change cases they had encountered. The respondents listed 76 change cases. With these two strategies, 112 lower level codes were identified. These individual codes identified in the first step were subsequently grouped to form eight upper-level codes: background (7 lower level codes), contextual variable (16 lower level codes), cause (8 lower level codes), change cause (44 lower level codes), communication (8 lower level codes), design (6 lower level codes), effect (5 lower level codes), and tools (18 
lower level codes). The upper-level codes were formed to make sense of the rich data on a higher level. The listed change events were categorised regarding change sources, and a root cause analysis was conducted through constructing a cause-effect diagram.

The tool used to conduct the root cause analysis was the cause-and-effect or Ishikawa diagram (Andersen and Fagerhaug, 2006), named after its inventor Kaoru Ishikawa. The tool was initially developed in the 1960s for quality improvement to identify possible causes of variation in a manufacturing process but has since been used for various types of root cause identifications, including an investigation on rework causes in hospital design by Feng and Tommelein (2009). The diagram is a way to systematically group and analyse causes, and evaluate which might be the root causes (Andersen and Fagerhaug, 2006). The specific change events recognised and listed from the interviews were used as data for the diagram. First, the individual change events were analysed systematically, first recognising the source category and then investigating further, what triggered the change to reach the root causes. Two levels of change causes inside each source category were identified in this way, each going deeper into the issue. Typically, there were only one or two specific change events per the lowest level cause.

\section{Findings and discussion}

First, this section presents and discusses the findings of the root cause analysis. After that, the study aims to propose ways to prepare for and manage changes in hospital construction projects.

\subsection{The root causes of changes in hospital construction projects}

The eight main branches of this paper's Ishikawa diagram consists of main sources of changes that are adapted from the taxonomy of Sun and Meng (2009) and interviews. The client as a source of change was divided into two categories, 1) Users and 2) Owner, as the user organisation and the project owner organisation were two distinct players with different priorities and skills. 3) Design, 4) Contractor and 5) External environment categories were also recognised from existing literature. Specific to hospital construction, two new categories were created: 6) Equipment and systems, and 7) Operations. These emerged mainly based on the interviews, but also the reviewed literature mentioned these unique characteristics in hospital construction. Both of these 
novel categories are interesting because they combine internal project decisions with external influences as sources of change. An additional category named 8) Contractual relationships was also added because it was seen as an important contextual factor causing project change and steering stakeholder actions. Figure 2 presents a three-level cause-effect diagram with the eight identified root cause categories. Next, each category is described in detail, starting from the most frequently mentioned and ending with the least mentioned category.

\section{*** INSERT FIGURE 2 HERE ***}

** Figure 2 caption: A three-level cause-effect diagram of the causes of change. **

1) Equipment and systems, specifically related to the care operations, was the most frequently occurring category among the change events. The root causes were found in the technological uncertainty as well as the structural complexity of the interfaces between the medical equipment and the rest of the building. The medical equipment is procured as late as possible because medical equipment advances fast. The late decisions on large, expensive, and heavy equipment, such as imaging devices, cause challenges for the contractors because the devices have many connections to the MEP (mechanical, electrical, and plumbing) systems that need to be designed early on in the project. The structural complexity regarding the number and the interdependency of systems was mirrored as the structural complexity of the project organisations and difficulties in information flow between project parties. Also, the public procurement process added a layer of uncertainty about the timing of the decisions as well as a socio-political dimension.

2) User changes have a lot to do with socio-political complexity regarding power struggles between different users and user groups, who all want to have their wishes included in the design process. Also, 
3) Design omissions often stem from the difficulty of taking everything into account in advance. With experience, the designers are more likely to be successful in this. Design errors usually resulted from the existence of multiple, separate sets of drawings, and the lack of coordination between those sets. With a high degree of structural complexity between trades, ripple effects from other changes inside and between trades can occur.

4) External environment is a cause of many changes. Uncertainties related to the site conditions were often realised. External stakeholders can have much power on the hospital projects, especially those that enforce laws and regulations, and knowledge of local circumstances is needed to know the most important ones to consider.

5) Owner-initiated changes stem from the owner's position as the link between many external and internal stakeholders and the expectations they have for the project. Owners might face many cost pressures from political leaders, or from being a for-profit organisation, and need to balance investments and optimise the healthcare facility network as a whole.

6) Contractors in design-bid-build projects had a very limited influence to the design at the actual design stage, but at the same time, they are under much pressure to save costs because of the lowest bid tendering method. Moreover, the degree of structural complexity and system interdependence and the uncertainty of methods when working with new technologies, reflect contractor changes.

7) Changes in operations impose the underlying uncertainty about future operational and functional needs. The uncertainty originates from external influences in technology and medicine as well as in the demographics of the population to be treated.

8) Contracts are difficult to craft, especially if everything is tried to be included. They are legally binding but on the other hand not completely fixed. The more separate contracts and contract parties the project has, the more interfaces there are to manage and more communication needed.

The root cause analysis reveals that most of the root causes of change are directly related to the project complexity factors. Many of the typical hospital project characteristics are possible sources of project 
complexity. This analysis is supported by the interviews, where many respondents described hospital construction as different from other types of construction. Typical answers were related to the technology and systems, and less on the intangible sides of the project, such as goal alignment or stakeholder management. For example, a contractor from project $\mathrm{C}$ in Sweden described the technological complexity in the following way "You have so many different types of equipment that should be in the building that you have to take care, so it's quite a big issue." Moreover, the owner in project D in the USA described the technological novelty in the following way "We are building towards a moving target because when there's new technical development among the medical suppliers, we have to see how to get it in this project."

Table 3 combines the change source categories with the types of complexity affecting them, including the strength of the effect estimated from low to high. The table reveals that most of the sources of change are affected by multiple different types of complexity. In addition to the most established complexity dimensions related to hospital construction, structural complexity and uncertainty, and socio-political complexity seem to have a significant impact. Socio-political tensions emerged both between users and owner and between owner and contractor.

\section{*** INSERT TABLE 3 HERE ***}

** Table 3 caption: Change sources and corresponding complexity dimensions. The strength of effect from low $(+)$ to high $(+++) * *$

The identified sources of change interact within the project system. Figure 3 depicts change dynamics, i.e., how the different sources can influence each other. The internal stakeholders act on different levels, others 
having more to do with the decisions and others with the actual execution of the project. Operations, Equipment and systems, and External environment influence the process between the stakeholders. For example, Operations have an impact on a higher level as opposed to the External environment, which has the most significant impact on the execution. Changes on a higher level also affect downstream, influencing more project parties all the way to the executor level, finally accumulating at the contractor level.

The key finding of this analysis is that the changes stem from a variety of sources, which are influenced by various complexity factors and are interlinked with each other, as Figure 3 depicts. Therefore, it seems that it is not possible to identify just a few specific causes for hospital project changes, but it is advisable to admit that there is a complex change dynamic behind the causes. The interviewees also mentioned that the scope and timing of change affect the effect of the changes. For example, a substantial change usually is expensive if the construction work started a long time ago. Also, the predictability of the change and the number of trades affected impact the effect of the change. The interaction between the users and the designers plays a key role, whereas the owner and the contractor are the ones that deal with changes and 'suffer most' from them. A contractor from project B in Finland told that the owners do not always understand the effects of changes "When there's a change, it has a cost and schedule effect. Especially the schedule effect is usually the one that is hard for the client to understand." The owners told that the cost effects is their biggest concern. Thus, it is appropriate to ask how to improve the communication between these parties to mitigate the effects of changes. 


\subsection{Managing changes through product and process flexibility}

The studied case projects managed to avoid significant changes in scope, however, each project went through a series of design and other changes that shaped the end-product. The owners and contractors considered changes good for the project, when the changes solved functional challenges, improved the facilities, or enabled the use of the newest technology. The clients and users have been happy with the received hospital facilities, however; at the cost of project efficiency and timely project handover. Thus, there is potential for improving the capabilities to execute changes and achieve savings for all parties involved.

Changes took place continuously during the studied hospital construction projects. Some changes arose due to errors and omissions in the design or construction processes, whereas some changes happened due to the uncertain and dynamic hospital construction environment, which was reflected, e.g. as external changes in hospital equipment and internal changes in healthcare operations. The studied hospital construction projects prepared for the internal and external environmental changes through various means according to the interviewees. For example, by having clear goals that were communicated to each project stakeholder. A design coordinator was used as a translator between the users and the rest of the project stakeholders during the requirements elicitation phase. At the beginning of each work phase, a startup meeting was held to agree on common goals and work practices. Decisions were also scheduled to suit the needs of decision-makers and the construction process. These practices allowed for process flexibility, whereas product flexibility was also used. For example, standardisation of rooms was used a means to increase the flexibility of spaces but also to reduce user changes due to well-specified solutions. Another way to increase product flexibility was to design for the worst case, especially in case of medical equipment that can change at very late phases. These methods to increase product flexibility are in line with earlier findings by (Kyrö et al., n.d.). As a summary, the hospital projects applied both product and process flexibility to prepare for changes. Product and process flexibility functioned as a balancing force to project complexity, which confirms the earlier findings by Gil et al. (2005).

The findings of this study challenge the dominant view on construction change management according to which changes should be avoided because they create time and cost implications for the client, as Shipton et al. (2014) have observed. The ultimate goal of a construction project is to provide the best possible facilities 
for the operations, and the changes in many ways reflect this higher-level goal. The project needs to adapt to the changing dynamics when the project is executed, and the ability to do so may be increased through project flexibility, in the product and process dimensions, which is a balancing force to project complexity. This attitude is significantly different from the attitude traditionally associated with construction changes, which are usually considered as failures in the design and execution phases, causing a disturbance, costs, and delays (Burati Jr. et al., 1992; Love and Edwards, 2004; Olawale and Sun, 2010).

The findings of this paper shed light on what eventually causes changes in hospital construction projects. While the previous literature on hospital buildings and construction mainly emphasises uncertainty due to external changes in the healthcare service domain (de Neufville et al., 2008; Barlow and Köberle-Gaiser, 2009; Olsson and Hansen, 2010), this research provides evidence of several additional factors contributing to construction changes. The technological advancements in the healthcare industry induce changes, especially in the equipment area. Additionally, there are other sources of changes, such as political reasons, the contractual set-up, the expertise of the designers, owners and contractors, as well as unexpected outside influences. The socio-political dimension of complexity has not been emphasised in previous literature but was found to have a profound influence on many of the sources of change. Hence, the managers of hospital projects should be not only proficient in dealing with technical complexity but also be able to manage the different stakeholder groups and their interaction. This finding validates the previous finding on the importance of flexible strategies to manage the project as a system that faces many uncertainty factors (Ford and Bhargav, 2006).

The owners have much power on the organisational structure of the product when choosing a project delivery model that reflects the number of separate parties and their formal relationships. Based on the results of this study, it seems that a strong systems integrator role would be needed. During the construction phase, the role would best fit the general contractor. However, the general contractor is not necessarily positioned centrally enough to be able to fulfil the role. The findings suggest that the contractor would be willing to take a more significant role in the overall project planning to provide additional services and have their incentives linked to the performance of the end-product, rather than just to the project management success. However, despite the relative complexity of hospital construction projects, the project delivery approaches did not differ much when moving from the most straightforward projects to the more complex ones. This shows that to some extent 
there is an expectation that one universal approach would work best with all different types of projects, even though it has long ago been recognized in project management literature that understanding the context is a key success factor in project management (Shenhar and Dvir, 1996; Maylor et al., 2008).

The characteristics of the healthcare sector and cultural differences have been interpreted as significant factors affecting hospital projects and their flexibility (Olsson and Hansen, 2010). Similarities but also vast differences were recognised between the healthcare systems in the researched projects, mainly between the Nordics and the US. The ownership of hospital facilities was one crucial difference between Finland and Sweden but other underlying cultural differences affecting the way projects are executed might exist. For instance, Sweden is known for a very consensus seeking discussion culture, which affects how the internal project relationships are formed. Still, differences existed also between projects within the countries, signalling that project relationships are not solely dependent on cultural differences but also project-related factors are significant. 


\section{Conclusions}

The predominant view of literature on construction project management is that changes should be avoided. This view is understandable since changes in construction projects have been recognised as a primary cause for cost and schedule overruns as well as a source of dispute between project parties. However, the dynamism and uncertainty stemming from the hospital construction context challenge the traditional pursuit of stability in project management. This paper revealed that changes allow hospital construction projects to adapt to changing goals, and changes are often necessary and useful for the end-result of the project.

The complex dynamics faced by hospital construction projects cause a challenge to prepare for and manage changes in the projects. Previous research has not thoroughly evaluated how the different complexity factors arising from the unique project environment affect hospital construction. This paper explored the root causes of changes during the construction phase of hospital construction projects and proposed better ways to manage changes in hospital construction projects. The paper presents a framework for change dynamics and illustrates the hierarchy and interdependence of the different change causes (Figure 3). The paper is the first to link construction changes to project complexity factors.

Based on the findings of this paper, flexibility is one way to prepare for changes in hospital construction projects. The combination of product and process flexibility seemed to leave room to manoeuvre and not trump the overall efficiency of the projects. Hence, flexibility may be perceived as an antidote to complexity. Various means diminish the negative impacts of changes. Clear goals, a design coordinator, start-up meetings, the integration of decision-making schedules and the construction process, standardisation of spaces, and design for the worst are examples of product and process flexibility.

Future research is needed to further expand the results. This research only included traditional project delivery types, such as design-bid-build, design-build, and construction management, and found evidence for product and process flexibility. This study makes no claims of statistical generalisation or generalisation outside this researched context. Further comparative research on relational project delivery versus traditional project delivery is needed to understand how relational project deliveries differ in terms of applying flexibility. For 
example, it might be that contract or team flexibility play a role in managing project changes in relational project deliveries, as Zhang et al. (2013) estimate. Recent announcements about new hospital projects in Finland show that the trend might be moving to project management models of alliancing and partnering. This phenomenon will likely mean that the problems of typical project delivery methods have been noticed among the project owners, and attempts are made to explore other alternatives. Future research endeavours should focus on studying how these new project delivery methods differ in the change dimension and change management from traditional projects. 


\section{References}

Alaghbari, W., Razali A. Kadir, M., Salim, A. and Ernawati. (2007), "The significant factors causing delay of building construction projects in Malaysia", Engineering, Construction and Architectural Management, Vol. 14 No. 2, pp. 192-206.

Andersen, B. and Fagerhaug, T. (2006), Root cause analysis: Simplified tools and techniques, ASQ Quality Press, Milwaukee, Wisconsin, 2nded.

Bakhshi, J., Ireland, V. and Gorod, A. (2016), "Clarifying the project complexity construct: Past, present and future”, International Journal of Project Management, Vol. 34 No. 7, pp. 1199-1213.

Barlow, J. and Köberle-Gaiser, M. (2008), "The private finance initiative, project form and design innovation. The UK's hospitals programme", Research Policy, Vol. 37 No. 8, pp. 1392-1402.

Barlow, J. and Köberle-Gaiser, M. (2009), "Delivering innovation in hospital construction: Contracts and collaboration in the UK's private finance initiative hospitals program", California Management Review, Vol. 51 No. 2, pp. 126-144.

Biernacki, P. and Waldorf, D. (1981), "Snowball sampling: Problems and techniques of chain referral sampling", Sociological Methods and Research, Vol. 10 No. 2, pp. 141-163.

Burati Jr., J.L., Farrington, J.J. and Ledbetter, W.B. (1992), "Causes of quality deviations in design and construction", Journal of Construction Engineering and Management, Vol. 118 No. 1, pp. 34-49.

Cox, I.D., Morris, J.P., Rogerson, J.H. and Jared, G.E. (1999), "A quantitative study of post contract award design changes in construction”, Construction Management and Economics, Vol. 17 No. 4, pp. 427-439.

Dvir, D. and Lechler, T. (2004), "Plans are nothing, changing plans is everything: The impact of changes on project success", Research Policy, Vol. 33 No. 1, pp. 1-15.

Feng, P.P. and Tommelein, I.D. (2009), "Causes of rework in California hospital design and permitting: Augmenting an existing taxonomy", Proceedings of IGLC17: 17th Annual Conference of the International Group for Lean Construction, pp. 407-416.

Ford, D.N. and Bhargav, S. (2006), "Project management quality and the value of flexible strategies", Engineering, Construction and Architectural Management, Vol. 13 No. 3, pp. 275-289.

Geraldi, J., Maylor, H. and Williams, T. (2011), "Now, let's make it really complex (complicated): A systematic review of the complexities of projects", International Journal of Operations \& Production Management, Vol. 31 No. 9, pp. 966-990.

Gil, N., Tommelein, I.D., Stout, A. and Garrett, T. (2005), "Embodying product and process flexibility to cope with challenging project deliveries", Journal of Construction Engineering and Management, Vol. 131 No. 4, pp. 439-448.

Hellström, M. and Wikström, K. (2005), "Project business concepts based on modularity - Improved manoeuvrability through unstable structures", International Journal of Project Management, Vol. 23 No. 5, pp. 392-397.

Hsieh, T.Y., Lu, S.T. and Wu, C.H. (2004), "Statistical analysis of causes for change orders in metropolitan public works", International Journal of Project Management, Vol. 22 No. 8, pp. 679-686.

Ibbs, C.W. (1997), “Quantitative impacts of project change: Size issues”, Journal of Construction Engineering 
and Management, Vol. 123 No. 3, pp. 308-311.

Kyrö, R., Peltokorpi, A. and Luoma-Halkola, L. (n.d.). "Connecting adaptability strategies to building system lifecycles in hospital retrofits", Engineering Construction and Architectural Management, p. Accepted for publication.

Lavikka, R., Smeds, R. and Jaatinen, M. (2015), "Coordinating collaboration in contractually different complex construction projects", Supply Chain Management: An International Journal, Vol. 20 No. 2, pp. 205-217.

Lehtinen, J., Peltokorpi, A. and Artto, K. (2019), "Megaprojects as organizational platforms and technology platforms for value creation", International Journal of Project Management, Vol. 37 No. 1, pp. 43-58.

Love, P.E.D. and Edwards, D.J. (2004), "Determinants of rework in building construction projects", Engineering, Construction and Architectural Management, Vol. 11 No. 4, pp. 259-274.

Maylor, H., Vidgen, R. and Carver, S. (2008), "Managerial complexity in project-based operations: A grounded model and its implications for practice", Project Management Journal, Vol. 39 No. S1, pp. S15-S26.

de Neufville, R., Lee, Y.S. and Scholtes, S. (2008), "Using flexibility to improve value-for-money in hospital infrastructure investments", 2008 1st International Conference on Infrastructure Systems and Services: Building Networks for a Brighter Future, INFRA 2008, No. October, doi:10.1109/INFRA.2008.5439668.

Olawale, Y. and Sun, M. (2010), "Cost and time control of construction projects: Inhibiting factors and mitigating measures in practice", Construction Management and Economics, Vol. 28 No. 5, pp. 509526.

Olsson, N.O.E. (2006), "Management of flexibility in projects", International Journal of Project Management, Vol. 24 No. 1, pp. 66-74.

Olsson, N.O.E. and Hansen, G.K. (2010), "Identification of critical factors affecting flexibility in hospital construction projects", HERD: Health Environments Research \& Design Journal, Vol. 3 No. 2, pp. 30 47.

Pauget, B. and Wald, A. (2013), "Relational competence in complex temporary organizations: The case of a French hospital construction project network", International Journal of Project Management, Vol. 31 No. 2, pp. 200-211.

Saunders, M., Lewis, P. and Thornhill, A. (2007), Research Methods for Business Students, Pearson Education Limited, Essex, 4thed.

Sebastian, R. (2011), "Changing roles of the clients, architects and contractors through BIM", Engineering, Construction and Architectural Management, Vol. 18 No. 2, pp. 176-187.

Senaratne, S. and Sexton, M.G. (2009), "Role of knowledge in managing construction project change", Engineering, Construction and Architectural Management, Vol. 16 No. 2, pp. 186-200.

Shenhar, A.J. and Dvir, D. (1996), "Toward a typological theory of project management", Research Policy, Vol. 25 No. 4, pp. 607-632.

Shipton, C., Hughes, W. and Tutt, D. (2014), "Change management in practice: An ethnographic study of changes to contract requirements on a hospital project", Construction Management and Economics, Vol. 32 No. $7-8$, pp. 787-803.

Sivunen, M., Kajander, J.K., Kiiras, J. and Toivo, J. (2014), "Managing risks related to functional changes by 
Design Alliance", Procedia Engineering, Vol. 85, pp. 473-481.

Sun, M., Fleming, A., Senaratne, S., Motawa, I. and Yeoh, M.L. (2006), “A change management toolkit for construction projects", Architectural Engineering and Design Management, Vol. 2 No. 4, pp. 261-271.

Sun, M. and Meng, X. (2009), "Taxonomy for change causes and effects in construction projects", International Journal of Project Management, Vol. 27 No. 6, pp. 560-572.

Williams, T.. (1999), “The need for new paradigms for complex projects", International Journal of Project Management, Vol. 17 No. 5, pp. 269-273.

Yin, R.K. (2003), Case study research: design and methods, Sage Publications, Thousand Oaks, 3rded.

Zhang, L., He, J. and Zhou, S. (2013), "Sharing tacit knowledge for integrated project team flexibility: case study of integrated project delivery", Journal of Construction Engineering and Management, Vol. 139 No. 7 , pp. 795-804.

Zhao, Z.Y., Lv, Q.L., Zuo, J. and Zillante, G. (2010), "Prediction system for change management in construction project", Journal of Construction Engineering and Management, Vol. 136 No. 6, pp. 659669. 


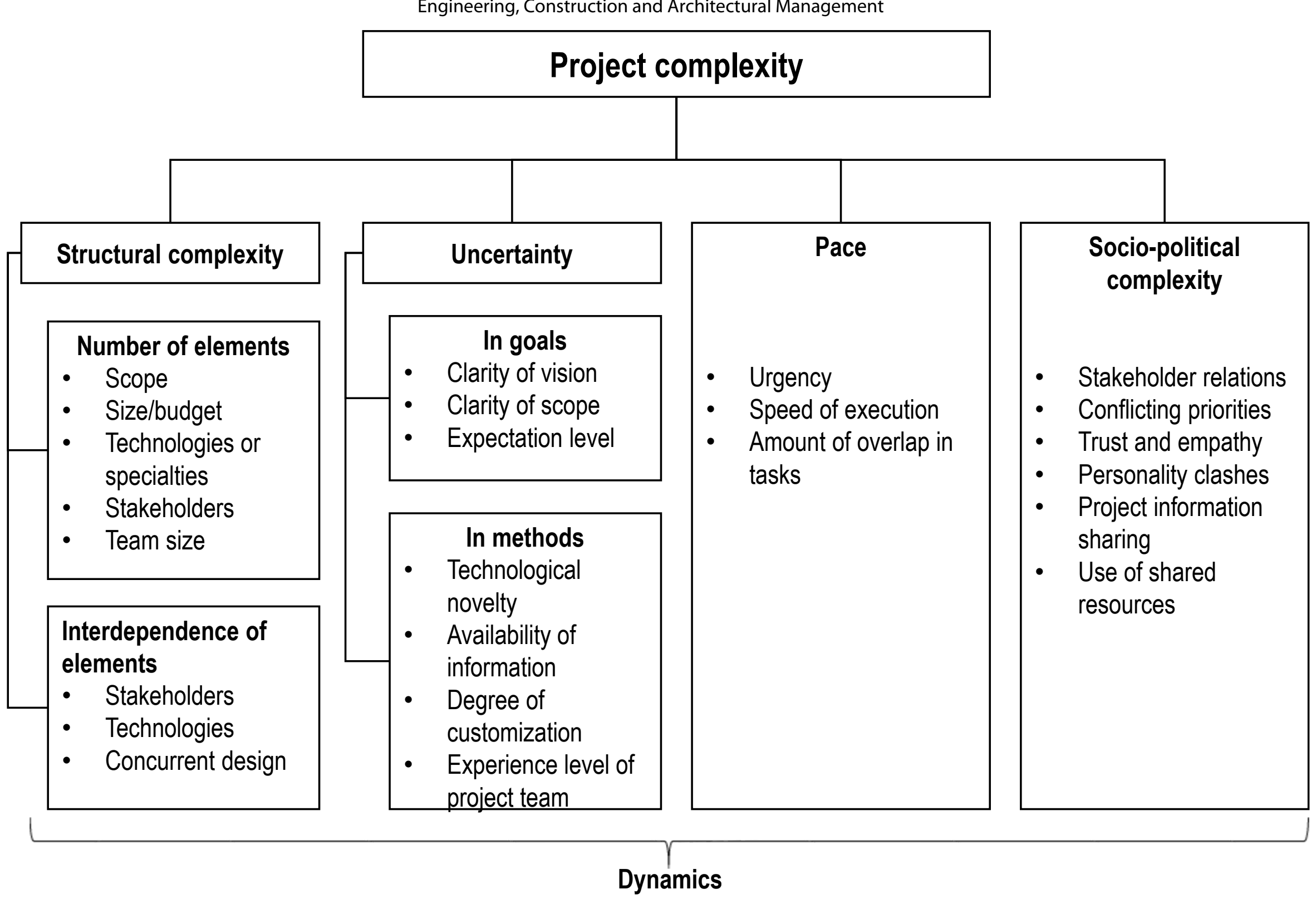

Figure 1. The dimensions of project complexity and examples of complexity indicators. 
Table 1. Summary of case projects.

\begin{tabular}{|c|c|c|c|c|c|}
\hline & Project A & Project B & Project C & Project D & Project E \\
\hline Country & Finland & Finland & Sweden & Sweden & USA \\
\hline $\begin{array}{l}\text { Time of } \\
\text { completion }\end{array}$ & 2016 Q2 & 2015 Q2 & 2017 & 2017 & 2017 \\
\hline Total cost & $\begin{array}{l}\text { EUR } 35 \mathrm{~m} \\
\text { (Total) } \\
\text { EUR 23m } \\
\text { (Phase 2) }\end{array}$ & EUR 100m & $\begin{array}{l}\text { EUR } 115 \mathrm{~m} \\
\text { (New build) }\end{array}$ & EUR 190m & EUR $187 \mathrm{~m}$ \\
\hline Total area & $\begin{array}{l}6000 \mathrm{~m}^{2} \\
(\text { Phase 1) } \\
12000 \mathrm{~m}^{2} \\
\text { (Phase 2) }\end{array}$ & $36300 \mathrm{~m}^{2}$ & $\begin{array}{l}22000 \mathrm{~m}^{2} \\
\text { (New-build) }\end{array}$ & $21000 \mathrm{~m}^{2}$ & $27000 \mathrm{~m}^{2}$ \\
\hline $\begin{array}{l}\text { Project } \\
\text { delivery } \\
\text { method }\end{array}$ & $\begin{array}{l}\text { Design-Bid- } \\
\text { Build } \\
\text { ( } 2 \text { phases with } \\
\text { different } \\
\text { contractors) }\end{array}$ & $\begin{array}{l}\text { Design-Bid- } \\
\text { Build with } \\
\text { Construction } \\
\text { Management }\end{array}$ & Design-Build & $\begin{array}{l}\text { Design-Bid- } \\
\text { Build }\end{array}$ & $\begin{array}{l}\text { Design-Assist } \\
\text { with } \\
\text { Construction } \\
\text { management }\end{array}$ \\
\hline $\begin{array}{l}\text { Contract } \\
\text { type }\end{array}$ & $\begin{array}{l}\text { Divided lump } \\
\text { sum / Multi } \\
\text { prime }\end{array}$ & $\begin{array}{l}\text { Cost plus / GMP } \\
\text { (for general } \\
\text { contractor, } \\
\text { others lump } \\
\text { sum) }\end{array}$ & Cost plus / GMP & $\begin{array}{l}\text { Lump sum, Unit } \\
\text { price }\end{array}$ & Cost plus / GMP \\
\hline $\begin{array}{l}\text { Spaces } \\
\text { included }\end{array}$ & $\begin{array}{l}\text { Psychiatric } \\
\text { hospital: } \\
\text { Inpatient wards } \\
\text { for children, } \\
\text { youth and adults } \\
\text { Outpatient wards } \\
\text { Rehabilitation } \\
\text { and therapeutic } \\
\text { spaces } \\
\text { PET-TT imaging }\end{array}$ & $\begin{array}{l}\text { 24/7 hospital: } \\
\text { Operating rooms } \\
\text { ICU } \\
\text { Maternity ward } \\
\text { Sterile } \\
\text { processing } \\
\text { Dialysis } \\
\text { Outpatient wards } \\
\text { Cafeteria }\end{array}$ & $\begin{array}{l}\text { 24/7 hospital: } \\
\text { Operating rooms } \\
\text { ICU } \\
\text { Maternity ward } \\
\text { Sterile } \\
\text { processing } \\
\text { Imaging } \\
\text { Emergency } \\
\text { room }\end{array}$ & $\begin{array}{l}\text { Imaging and } \\
\text { surgical units: } \\
\text { Operating rooms } \\
\text { including hybrid } \\
\text { ORs } \\
\text { Imaging (X-ray, } \\
\text { PET, MRI, CT) } \\
\text { Sterile } \\
\text { processing } \\
\text { Cyclotron }\end{array}$ & $\begin{array}{l}\text { Patient tower: } \\
\text { Inpatient wards } \\
\text { ICU } \\
\text { Pharmacy } \\
\text { Laboratories } \\
\text { Sterile } \\
\text { processing }\end{array}$ \\
\hline Owner type & Public & Public & Public & Public & Private \\
\hline
\end{tabular}

GMP = guaranteed maximum price

Multi prime $=$ the use of multiple contractors to construct a project 
$\mathrm{ICU}=$ intensive care unit 
Table 2. Informants' organization, role, and project.

\begin{tabular}{llll}
\hline Organization(s) & Role & Project (country) & Date of interview \\
\hline General & Project manager & A (Finland) & 24.10 .2016 \\
General & Site manager & A (Finland) & 8.11 .2016 \\
Designer & Main architect & A (Finland) & 14.11 .2016 \\
User & Chief medical officer & A (Finland) & 14.11 .2016 \\
User & District manager & A (Finland) & 25.10 .2016 \\
Owner & Trade supervisor & A (Finland) & 25.10 .2016 \\
Owner & Design coordinator & A (Finland) & 2.11 .2016 \\
\hline Designer & Design coordinator & B (Finland) & 24.10 .2016 \\
General & Project manager & B (Finland) & 24.10 .2016 \\
Owner & Project engineer & B (Finland) & 24.10 .2016 \\
Owner & Project manager & B (Finland) & 14.11 .2016 \\
Owner & Trade supervisor & B (Finland) & 31.10 .2016 \\
Owner & Trade supervisor & B (Finland) & 4.11 .2016 \\
\hline General & Project manager & C (Sweden) & 19.10 .2016 \\
General & Construction manager & C (Sweden) & 19.10 .2016 \\
General & Design manager & C (Sweden) & 18.11 .2016 \\
\hline General & Project manager & D (Sweden) & 17.11 .2016 \\
Owner & Design coordinator & D (Sweden) & 17.11 .2016 \\
Owner & Project manager & D (Sweden) & 17.11 .2016 \\
Subcontractor & Project manager & D (Sweden) & 17.11 .2016 \\
\hline General & Senior project engineer & E (USA) & 7.12 .2016 \\
General & Senior project manager & E (USA) & 7.12 .2016 \\
General & Project controls engineer & E (USA) & 7.12 .2016 \\
General & Project manager & E (USA) & 7.12 .2016 \\
\hline & & & \\
\hline & & & \\
\hline & & & \\
\hline
\end{tabular}


Contractors

Owner Engineering, construction andAesignt

Page 30 of 32

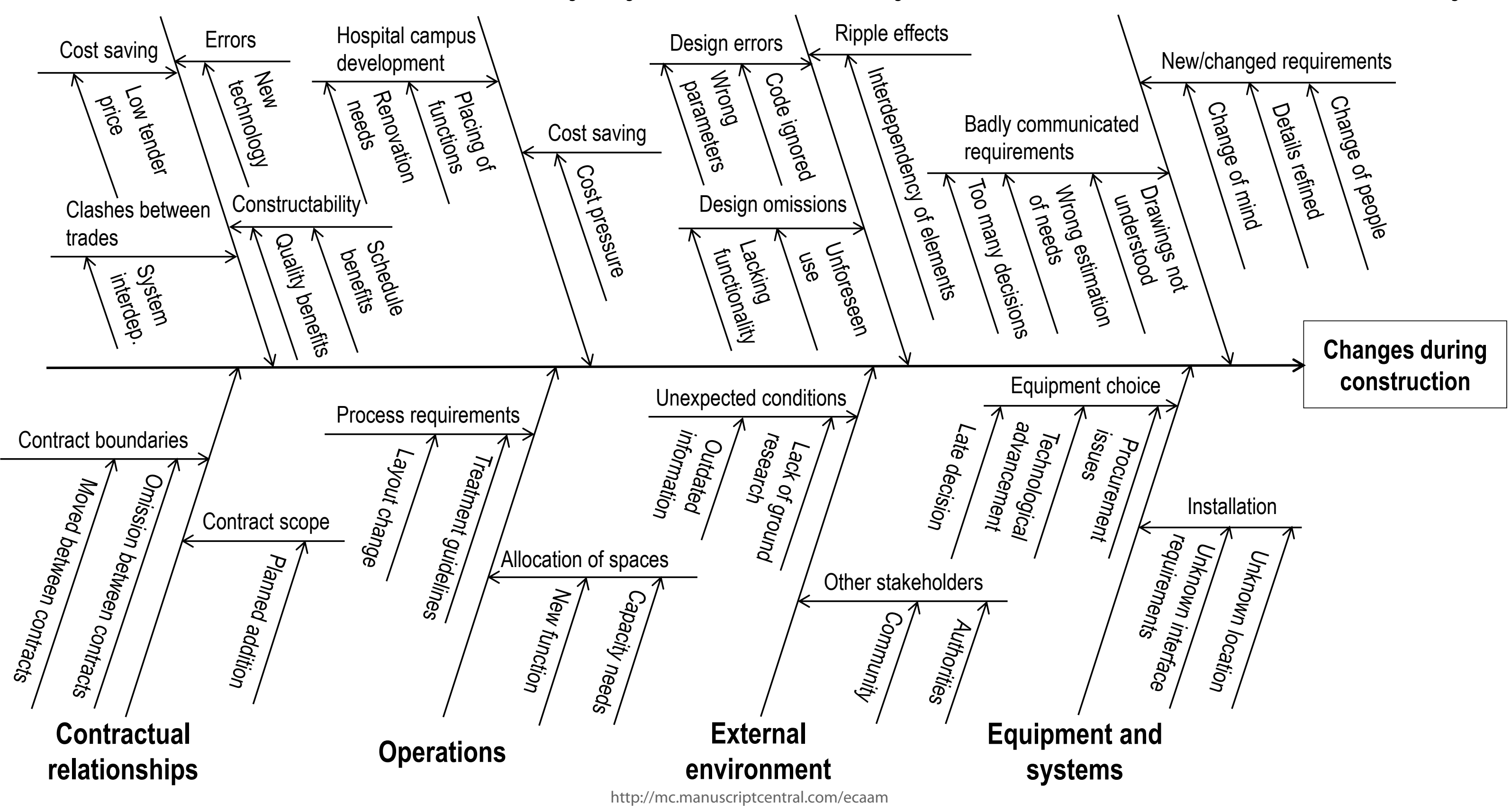

${ }_{41}^{4}$ igure 2: A three-level cause-effect diagram of the causes of change. 
Table 3. Change sources and corresponding complexity dimensions. The strength of effect from low $(+)$ to high $(+++)$.

\begin{tabular}{lccccc} 
& & & & \\
& $\begin{array}{c}\text { Structural } \\
\text { complexity }\end{array}$ & Uncertainty & Pace & $\begin{array}{c}\text { Socio-political } \\
\text { complexity }\end{array}$ & Dynamics \\
Equipment and systems & +++ & ++ & + & + \\
\hline Users & + & + & & ++ & + \\
\hline Design & +++ & ++ & + & & + \\
\hline
\end{tabular}

$\begin{array}{lll}\text { External environment } & ++ & ++\end{array}$

\begin{tabular}{lllll} 
Owner & ++ & ++ & + \\
\hline
\end{tabular}

\begin{tabular}{lllll} 
Contractors & ++ & + & + & + \\
\hline Operations & & + & & + \\
\hline
\end{tabular}

Contractual relationships

$++$ 
Owner

Defining the scope of project

Users
Making operations work
in practice

\section{Designers}

Turning requirements and restrictions to design

\section{Contractual relationships Division of work}

Execution

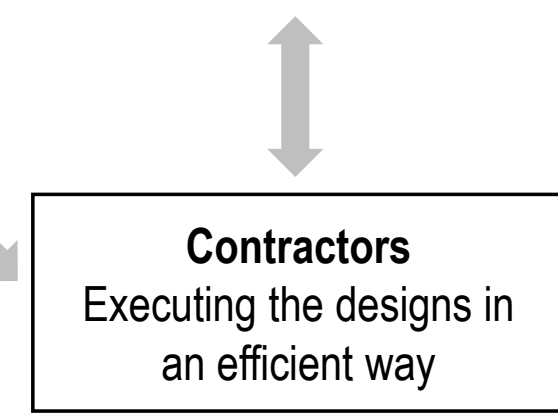

\section{Operations}

Care trends and needs, demographics

Equipment and systems Technology

External environment Unexpected conditions, external stakeholders

Figure 3: The change dynamics of the sources of change. 